\title{
Response of tropical birds to habitat modifications in fragmented forest patches: A case from a tropical lowland rainforest in south-west Sri Lanka
}

\author{
P. Perera ${ }^{1,4}$, S. Wijesinghe ${ }^{1}$, N. Dayawansa ${ }^{2}$, S. Marasinghe $^{1}$ and C. Wickramarachchi ${ }^{3}$ \\ IDepartment of Forestry and Environmental Science, University of Sri Jayewardenepura, Nugegoda, Sri Lanka \\ ${ }^{2}$ Department of Zoology, University of Colombo, Sri Lanka \\ ${ }^{3}$ Department of Statistics, University of Sri Jayewardenepura, Nugegoda, Sri Lanka \\ ${ }^{4}$ Corresponding Author. Phone: (+94) 112758411, Fax: (+94) 112803470,E-mail: priyan@sjp.ac.lk
}

Keywords: Ecotone, Forest-home garden interface, Forest specialists, Fragmented forest patches, Habitat association, Tropical birds.

\begin{abstract}
Disturbed forest fragments comprise a substantial proportion of tropical landscapes, and these habitats along with associated ecotones have become important to tropical biodiversity conservation in human-modified landscapes. This study evaluated how tropical avifaunal communities respond to moderate habitat disturbances, such as shifting cultivation, selective logging and restoration from exotic plant species, in the Yagirala Forest Reserve, a fragmented tropical lowland rainforest in south-west Sri Lanka. Thirty circular plots with a $25-\mathrm{m}$ fixed-radius, located to cover four prominent habitat types (secondary forest, Pinus-dominated forest, abandoned paddy lands and home gardens), were studied from March to December 2014. The results suggest that despite being fragmented and disturbed by human actions, the Yagirala Forest Reserve and associated ecotone collectively provide an important refuge for avifauna in the landscape context. The forest-home garden interface supported the highest avifaunal diversity. Edge habitats represented by home gardens and abandoned paddy lands generally supported greater bird richness. However, less disturbed secondary forest and Pinus-dominated forest were be more important for endemic and forest-specialist birds. Our results further highlight the potential value of wooded forest-home garden interfaces and forest stands restored with exotic pines in supporting native forest bird assemblages, especially in fragmented and isolated forest patches.
\end{abstract}

Nomenclature: BirdLife International (2015).

Abbreviations: AP-Abandoned paddy; HG-Home garden; PF-Pine-dominated forest; SF-Secondary forest.

\section{Introduction}

Habitat loss, fragmentation, and degradation of habitat quality are considered the main drivers of biodiversity loss and result in habitats modified or newly created and maintained via anthropogenic influences (Fischer and Lindenmayer 2007, Mortelliti et al. 2010). Vulnerability and response of faunal species to habitat loss and modification can vary widely (Johns 1991, Silva et al. 2016). Among other taxonomic groups, birds have been identified as a good indicator of overall habitat quality, as birds are more sensitive to disturbance, while being predominantly diurnal and easily identifiable (Gray et al. 2007, Gibson et al. 2011, Goodale et al. 2013).

Comparative studies of how birds utilize landscapes of human-modified ecosystems - such as agricultural lands (Estrada et al. 1997, Daily et al. 2001, Herzog et al. 2005), paddy fields (Bambaradeniya et al. 2004), agroforestry systems (Beukema et al. 2007, Van Bael et al. 2007, Bhagwat et al. 2008), forest plantations (Marsden et al. 2001, Irwin et al. 2014) and natural forest fragments (Antongiovanni and Metzger 2005, Martínez-Morales 2005, Fischer and Lindenmayer 2007, Barzan et al. 2015) — have been docu- mented in the literature. These studies suggest that bird species richness in human-modified ecosystems can be as high as in natural forest fragments, but often support different assemblages of species. The loss of structural diversity in natural forests due to fragmentation and degradation can reduce bird richness and change the composition of bird communities (Zurita et al. 2006). Recent studies in the tropics have investigated the bird community composition in forested and disturbed habitats by humans (Renjifo 2001, Hughes et al. 2002, Waltert et al. 2004, Ranganathan et al. 2010, Goodale et al. 2013). These studies highlight the importance of maintaining intact forests in sustaining tropical forest bird communities within human-dominated landscapes (Ranganathan et al. 2010), although overall improvement of the landscape matrix for biodiversity conservation through secondary habitats has also been emphasized (Waltert et al. 2004, Goodale et al. 2013).

Sri Lanka, along with the Western Ghats in India, is considered one of the world's 34 biodiversity hotspots (Myers et al. 2000). Sri Lanka supports a rich avifauna with 453 recorded species at present. This includes 240 breeding residents, of which 27 species are considered endemic and another 6 species are proposed as endemic (Ministry of Environment 
2012). Tropical lowland rainforests in the country harbor over $70 \%$ of the endemic bird species. However, there are only 123,302 ha of tropical lowland rainforests remaining at present, which is approximately $1.9 \%$ of the country's natural forest cover (Edirisinghe et al. 2012). Apart from the Sinharaja World Heritage Forest, which is the country's largest remaining virgin tropical lowland rainforest, the others remain largely fragmented, disturbed and isolated throughout the south-west lowlands of Sri Lanka. In addition to gradual outright forest clearance that occurred over the years due to human settlements and agriculture, many lowland rainforests in south-west Sri Lanka were further subjected to selective logging during the 1970s to meet the demand of the plywood industry (Forestry Sector Master Plan 1995). Forest policy reforms in 1990 resulted in designating the remaining natural forests in the country for conservation purposes, while the moratorium of logging in natural forests imposed in 1990 prevented exploitation of natural forest for timber (Ekanayake and Theodore 2017). However, encroachments and illegal exploitation of forests still prevail, threatening the rich biodiversity associated with these forests.

This study was performed in the Yagirala Forest Reserve, which is a fragmented and isolated tropical lowland rainforest located in South-west Sri Lanka. Exposure to varying degrees of anthropogenic disturbances and long-term isolation of the forest remnant in a landscape matrix dominated by different agricultural land uses makes Yagirala forest an ideal case to assess the impacts of habitat loss and degradation on tropical avifauna. As there is rather limited information on the potential value of isolated forest fragments for tropical forest bird species and how these birds respond to moderate forest disturbances (Waltert et al. 2004, Gray et al. 2007, Barzan et al. 2015), we studied the composition and diversity of bird assemblages of habitats subjected to such disturbances. We further tested the null hypothesis that the bird species assemblages in major habitat types that represent different degrees of anthropogenic disturbances are similar.

\section{Methods}

The study site: Yagirala Forest Reserve is located in the south-west low-country wet zone of Sri Lanka (Fig. 1A; $6^{\circ} 21$ ' to $6^{\circ} 26^{\prime} \mathrm{N}$ and $80^{\circ} 08^{\prime}$ to $80^{\circ} 11^{\prime} \mathrm{E}$ ). It is a fragmented forest measuring 2,004.9 ha (Fig. 1B). The area receives an annual average rainfall of over 3,200 $\mathrm{mm}$ during both the North-East monsoons from November to January and the South-West monsoons during May to September. The mean annual temperature ranges from $27.0^{\circ} \mathrm{C}$ to $28.5^{\circ} \mathrm{C}$ (Punyawardena et al. 2003).

The Yagirala forest was selectively logged during the late 1970s. It was contiguous with adjacent forests in the past, but became fragmented over the years due to human settlements and land conversion for agriculture, especially for rubber (Hevea brasiliensis), paddy (Oryza sativa) and tea (Camellia sinensis) cultivation. The 2,004.9 ha area declared as a forest reserve contains naturally regenerated secondary forest, abandoned paddy lands and degraded lands replanted mainly with exotic Pinus carribea. Natural, semi-natural and human modified habitats in and around the Yagirala Forest Reserve form a mosaic landscape. The bird census was confined to four such prominent land-use/habitat types, extending over approximately 420 ha of accessible area of the forest (Fig. 1C). The main characteristics of these habitats are summarized in Table 1. Secondary forest and Pinus-dominated forest represent forest interior habitats, while abandoned paddy lands and home gardens represent edge habitats.

\section{Bird census}

A bird census was performed using 25-m fixed-radius point counts. Point counts for a $25-\mathrm{m}$ radius have been recommended for bird census in tropical forests where visibility is comparatively low (Bibby 2000, Sutherland 2006). A total of 30 permanent point-count stations were established to cover the four prominent habitat types selected. The number of point count stations and their locations within each land use type were determined based on the approximate extent of each habitat type available in the site map and a ground reconnaissance survey. The ability to access the sampling sites without disturbance was a major consideration in select-

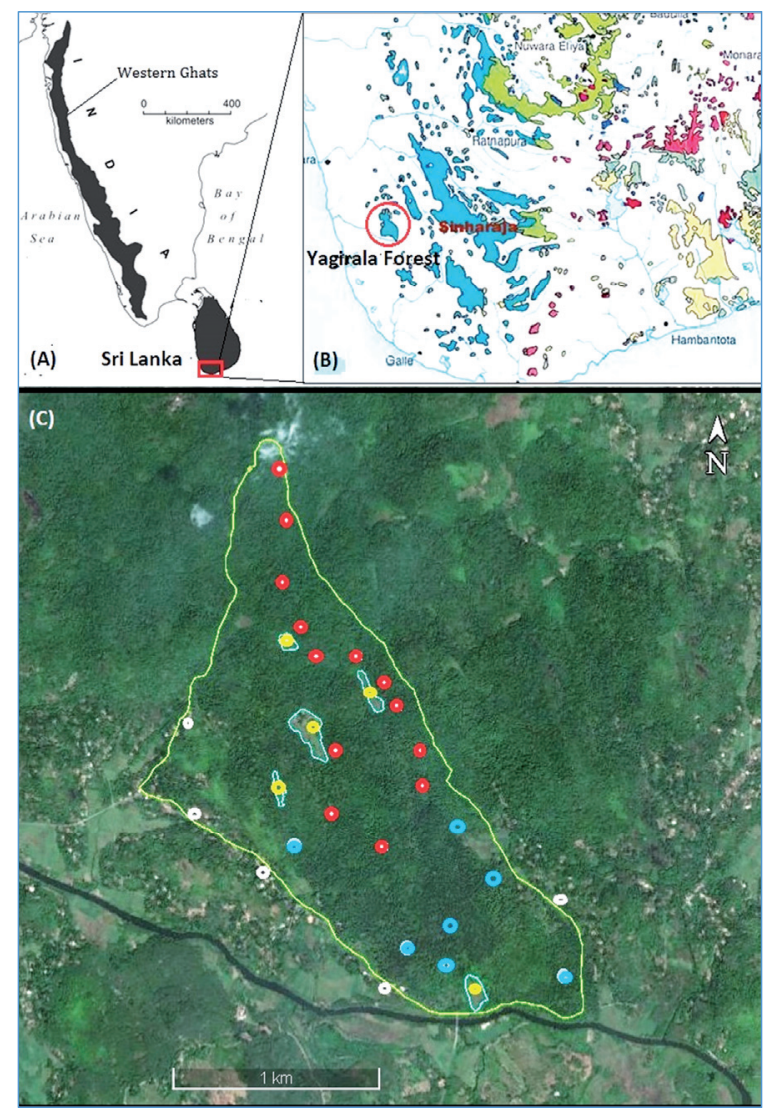

Figure 1. The study site Yagirala Forest Reserve. A: Location of Sri Lanka, along with the Western Ghats in India, which are considered a biodiversity hotspot. B: The remaining fragmented tropical lowland rainforests (indicated in light blue) scattered throughout south-west Sri Lanka. C: Location of sampling sites in each habitat type (AP-yellow; HG-white; $\mathrm{PF}-$ blue; $\mathrm{SF}-$ red). 
Table 1. Description of main habitats/land-use types studied.

\begin{tabular}{|c|c|}
\hline Habitat type & Description \\
\hline $\begin{array}{l}\text { Secondary } \\
\text { forest (SF) }\end{array}$ & $\begin{array}{l}\text { Selectively logged forest naturally regenerated after logging operations ceased in } 1979 \text {. The forest has a canopy cover } \\
\text { of } 75 \text { to } 85 \% \text { with stratification clearly identifiable. Canopy height is } 25-40 \mathrm{~m} \text {, dominated by Dipterocarpus zeylanicus, } \\
\text { Mesua ferrea, Pericopsis mooniana, Artocarpus heterophyllus, and Artocarpus nobilis. Sub-canopy (15-25 m), is dom- } \\
\text { inated by Chaetocarpus castanocarpus, Garcinia hermonil, Xylopia championi, Horsfieldia iriyaghedhi, and Myristica } \\
\text { dactyloides. Understory varies from 5-10 m with a sparse shrub layer. Secondary forest accounted for approximately } \\
260 \text { ha of the study area. }\end{array}$ \\
\hline $\begin{array}{l}\text { Pinus- } \\
\text { dominated } \\
\text { forest (PF) }\end{array}$ & $\begin{array}{l}\text { Areas that were heavily logged or cleared for agriculture before the } 1970 \text { s and restored with exotic Pinus carribea } \\
\text { during the } 1970 \text { 's. These restored areas have been left without any management and thus are in the process of being } \\
\text { replaced by native tree species (such as Dillenia retusa, Sandoricum koetjape, Schumacheria castaneifolia, Thottea } \\
\text { siliquosa, and Coscinium fenestratum), with a natural death of pines. Canopy cover is } 70-75 \text { percent. The undergrowth } \\
\text { is dominated by densely grown Ochlandra stridula up to } 3 \text { m height. Pinus-dominated forest covers approximately } 130 \\
\text { ha of the study area. }\end{array}$ \\
\hline $\begin{array}{l}\text { Abandoned } \\
\text { paddy lands } \\
(\text { AP) }\end{array}$ & $\begin{array}{l}\text { Human-modified patches of open marsh inside and on the periphery of the forest, collectively accounting for ap- } \\
\text { proximately } 15 \text { ha. These habitats are dominated by grasses and surrounded by forest vegetation. These lands have } \\
\text { been used to grow paddy under shifting cultivation bases till } 1990 \text { and were abandoned after the forest was declared a } \\
\text { reserve. }\end{array}$ \\
\hline $\begin{array}{l}\text { Home gardens } \\
(\mathrm{HG})\end{array}$ & $\begin{array}{l}\text { Human-modified habitats immediately bordering the forest (forest-home garden interface) with tea (Camellia sinensis) } \\
\text { as the dominant crop. Gliricidia sepium trees are maintained at 3-5 m height as shade trees for the tea crop. Multi- } \\
\text { purpose and fruit trees in these well-wooded home gardens (Murraya koenigii, Carica papaya, Mangifera indica, } \\
\text { Artocarpus heterophyllus, Cocos nucifera) vary from } 2 \text { to } 15 \mathrm{~m} \text { in height. }\end{array}$ \\
\hline
\end{tabular}

ing sampling locations in this type of terrain. Accordingly, 13 plots in the secondary forest, 7 plots in the Pinus-dominated forest, 5 plots in abandoned paddy lands, and 5 plots in home gardens (forest home-garden interface) were established. The high number of point-count stations in forest interior habitats also accounts for possible bias due to greater visibility in edge habitats, yielding a higher number of species (Sutherland 2006). The point-count stations were located at least $300 \mathrm{~m}$ apart. The rationale for adopting a minimum distance was to minimize the likelihood of encountering the same individual bird on adjacent point counts (Blake and Loiselle 2001, Silva et al. 2016).

During the study period from March to December 2014, each plot was visited on at least 8 occasions between 06:00 hrs and 18:00 hrs. Data were collected from each study plot at least once a month. Accordingly, a total of 318 point counts were completed during the study period. The field observer visited each point count at various times by dividing the daily observation period into six equal time intervals (2-hour intervals), and visited in a different order to avoid visiting the same sampling point at the same time interval more frequently during the field seasons. Each station was surveyed for 10 minutes (Sutherland 2006). All birds that were seen and heard within a $25 \mathrm{~m}$ radius from the center of the plot were recorded. The same-field observer conducted all of the point counts to eliminate observer bias. Bird surveys were not performed on rainy days or during strong winds because these conditions affected the detection and presence of birds in their natural habitats. A standard binocular (Nikon Action ${ }^{\circledR}$ $8 \times 40$ ) was used to facilitate observations.

All bird species recorded were categorized into four habitat guilds and six feeding guilds representing the two resource groups of habitat and diet. Guilds based on preferred habitat included forest specialists, open-wetland-associated species, edge-associated species and habitat generalists, while frugivore, nectarivore, carnivore, omnivore, insectivore and granivore were the feeding guilds considered (Noss 1991, Gray et al. 2007). Birds were classified into one of the above mutually exclusive guilds for both resource groups, based on descriptions available in literature (Legge 1983, Henry 1998, Harrison 2011, Warakagoda et al. 2016)

\section{Data analysis}

Species richness, diversity and evenness were used to explore the complexity of avifaunal communities inhabiting each habitat type. The number of species counted in a site is usually considered a biased underestimate of total species richness, due to the problem of detectability of species (Magurran 2004). As the observed number of species is sensitive to the number of individuals counted or the area sampled, statistical comparison of species richness among sites can be challenging (Colwell et al. 2012, Gotelli and Chao 2013). Hence, to account for possible incomplete species inventories due to limited field sampling, species richness patterns were investigated using the estimated species richness for habitats using sample-based rarefaction curves in EstimateS 9.1.0 (Colwell 2013). The null hypothesis that "species richness does not significantly differ among habitat types" was tested using rarefied species richness with identical sampling effort.

Shannon index $\left(\mathrm{H}^{\prime}\right)$, a measure that incorporates both species richness and evenness, was used to compare bird diversity among habitats (Spellerberg and Fedor 2003, Magurran 2004). As this nonparametric measure makes no assumptions about the underlying species' abundance distribution and considers the relative proportions of species, Shannon index is widely used as a robust diversity measure in ecology (Magurran 2004, Gamito 2010).

We used non-metric multidimensional scaling ordination (NMDS) to compare bird species assemblages among habitats in two dimensions, using the Bray-Curtis dissimilarity mea- 
sure in the R statistical software Package vegan. To account for the influence of more abundant species, the abundances were square-root transformed prior to the analysis. The permutational multivariate analysis of variance using distance matrices (ADONIS) in the same software package was further used to test whether these bird assemblages would statistically differ from each other. Sorensen's dissimilarity index (Magurran 2004) was further used to test for dissimilarities in species composition between habitats. One-way ANOVA in MINITAB ${ }^{\circledR} 17$ statistical software was used to test differences in the abundance of each feeding guild among habitat types.

\section{Results}

\section{Diversity of birds in different habitats}

A total of 318 point counts were made at the 30 sampling stations. During the study period, a total of 2,641 individual birds belonging to 104 species and 45 families were recorded. The 104 avian species encountered included 92 breeding residents and 12 migrant species, and there were 13 endemic species among the recorded breeding residents (Appendix). The checklist of birds further included one critically endangered species, two endangered species, three vulnerable species and nine near-threatened species (BirdLife International 2015).

The average number of birds recorded per point count was highest in the secondary forest (Mean \pm SD: $12.34 \pm$ $1.24)$ followed by the abandoned paddy lands $(8.69 \pm 1.01)$, pine-dominated forest $(8.53 \pm 0.67)$ and home gardens $(7.70$ $\pm 0.93)$. One-way ANOVA tests further revealed that the average number of individual birds recorded per point count differed significantly among habitat types at the $\alpha=0.05$ significance level, with secondary forest substantially differing from the rest of the habitats $(F=34.234, p=0.002)$. The highest number of species was observed from home gardens (76), followed by the secondary forest (72), abandoned paddy lands (65) and pine-dominated forest (43). However, rarefaction curves indicate that the expected species richness with identical sampling size exhibits a pattern where home gardens have the highest bird richness, followed by abandoned paddy lands, secondary forest and pine-dominated forest (Figure 2).

Rarefaction curves did not reach an asymptotic maximum, suggesting the possibility of revealing additional species with increased sampling effort. Hence, the null hypothesis of "species richness does not significantly differ among vegetation types" was tested using rarefied species richness at the lowest sample size ( $n=43$ in home gardens). A significant difference in species richness among all vegetation types was observed (except for secondary forest and abandoned paddy), as indicated by the non-overlapping $95 \%$ confidence intervals of species accumulation curves (Figure 2). Differences are considered statistically insignificant when $95 \%$ confidence intervals (C.I.) overlap $(\alpha=0.05)$.

The highest Shannon diversity $\left(\mathrm{H}^{\prime}\right)$ was recorded from home gardens $\left(\mathrm{H}^{\prime}=3.515\right)$, followed by the secondary forest $\left(\mathrm{H}^{\prime}=3.314\right)$. The lowest species diversity was recorded from the pine-dominated forest (Table 2). Forested habitats collectively accounted for greater endemic bird species diversity, with SF recording the highest diversity. The mean number of endemic species recorded in each habitat type was further compared using One-way ANOVA. Secondary forest significantly differed from the other habitat types in terms of endemic species richness $(F=13.872, p=0.001)$.

\section{Habitat association of species}

Bird species recorded during the study were categorized into four habitat guilds based on their preferred habi-
Figure 2. Rarefaction curves based on expected bird richness (95\% CI) for the studied habitat types.

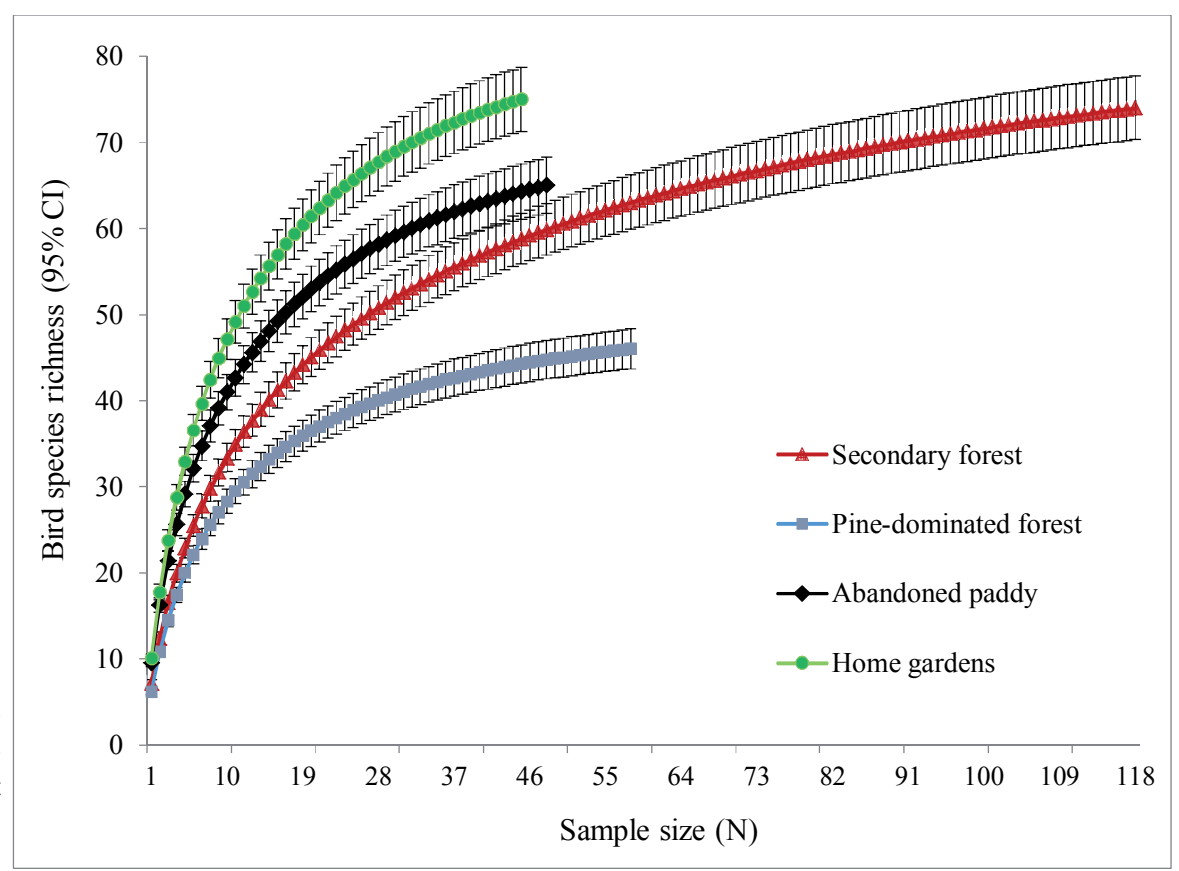


Table 2. Shannon diversity of birds in different habitats.

\begin{tabular}{lcc}
\hline \multicolumn{1}{c}{ Habitat type } & $\mathrm{H}^{\prime}$ & $\begin{array}{c}\mathrm{H}^{\prime} \text { for endemic } \\
\text { species }\end{array}$ \\
\hline Home gardens & 3.515 & 0.387 \\
Secondary forest & 3.314 & 0.621 \\
Abandoned paddy & 3.247 & 0.306 \\
Pine-dominated forest & 3.002 & 0.476 \\
\hline
\end{tabular}

tats. Accordingly, habitat generalists were the richest habitat guild, with 61 species, followed by forest specialists ( 22 species), edge-associated species ( 16 species) and open-wetlandassociated species, represented by five species (Appendix). The results of non-metric multidimensional scaling (NMDS) revealed two distinct bird assemblages across the four habitat types, of which one appears to be confined to forest interiors (represented by secondary-forest and pine-dominated forest habitats). The second is distributed in open edge habitats represented by abandoned paddy fields and home gardens bordering the forest (Figure 3). Birds from the four habitat guilds were further plotted in the NMDS ordination space, and the ellipses representing 95\% CI around the centroid of each habitat guild had different degrees of overlap. Ordination of forest specialist birds showed a close association with forest interior habitats, but habitat generalists were dispersed across all four habitat types. Ordination of edge-associated species was more related to home gardens, abandoned paddy fields and secondary forest, although the $95 \%$ CI indicates wide dispersion. Open-wetland-associated species ordination was closely associated with abandoned paddy fields and home gardens, with a restricted dispersion with a narrow 95\% CI around the centroid of the habitat guild.
Table 3. Sorensen's dissimilarity index of beta diversity.

\begin{tabular}{lccc}
\hline \multicolumn{1}{c}{ Habitat } & $\begin{array}{c}\text { Secondary } \\
\text { forest }\end{array}$ & $\begin{array}{c}\text { Pine- } \\
\text { dominated } \\
\text { forest }\end{array}$ & $\begin{array}{c}\text { Abandoned } \\
\text { paddy }\end{array}$ \\
\hline Pine-dominated forest & 0.588 & & \\
Abandoned paddy & 0.599 & 0.620 & \\
Home gardens & 0.629 & 0.661 & 0.558 \\
\hline
\end{tabular}

The results of subsequent ADONIS also suggested the existence of two distinct bird assemblages $(\mathrm{F}=3.932, \mathrm{p}<0.001)$. These observations were consistent with comparisons drawn using Sorensen's dissimilarity index. The Sorensen dissimilarity index ranged between 0.558 and 0.661 , indicating moderate levels of species overlap between habitat types. At the beta level, highest dissimilarity in bird species composition was observed between pine-dominated forest and home gardens, while home gardens and abandoned paddy habitats appear to have the highest number of shared species (Table 3).

The four-way Venn diagram (Fig. 4) further showed a substantial overlap of bird species among habitats. Of the 104 species, 76 bird species occurred in the overlapping portions of habitats, i.e., they were recorded in more than one habitat type. Twenty-eight species were restricted to a single habitat type. All 22 forest-specialist birds recorded in this study shared forest interior habitats (i.e., secondary forest and pine-dominated forest) with 20 sharing secondary forest and eight species recorded exclusively from secondary forests. All endemic species recorded in the study shared forest interior habitats (11 species occurring in secondary forest and five species occurring in pine-dominated forest). Of the 11 endemic species in a secondary forest habitat, four species were restricted exclusively to secondary forest.

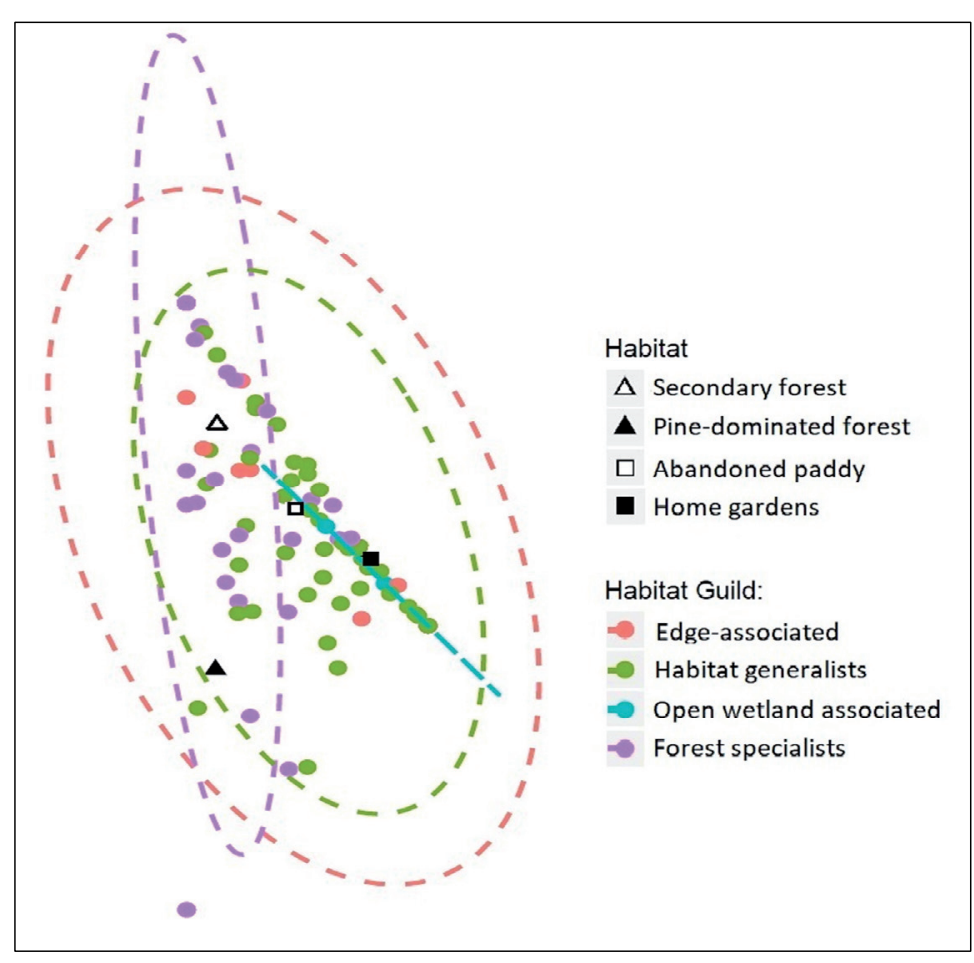

Figure 3. Non-metric multidimensional scaling ordination of bird assemblages in the four habitats based on square-root transformed abundance data and the Bray Curtis coefficient of similarity, plotted in two dimensions (2D Stress $=0.001)$. Ordination of habitat guilds with 95\% confidence interval around the centroid of each habitat guild (represented by different colors) are further indicated on the same two-dimensional space. 
Figure 4. Four-way Venn diagram showing number of shared species in each combination of four habitats. Pie charts in different habitat combinations show the fraction of habitat guilds for each shared number of species ("En" indicates number of endemic species).

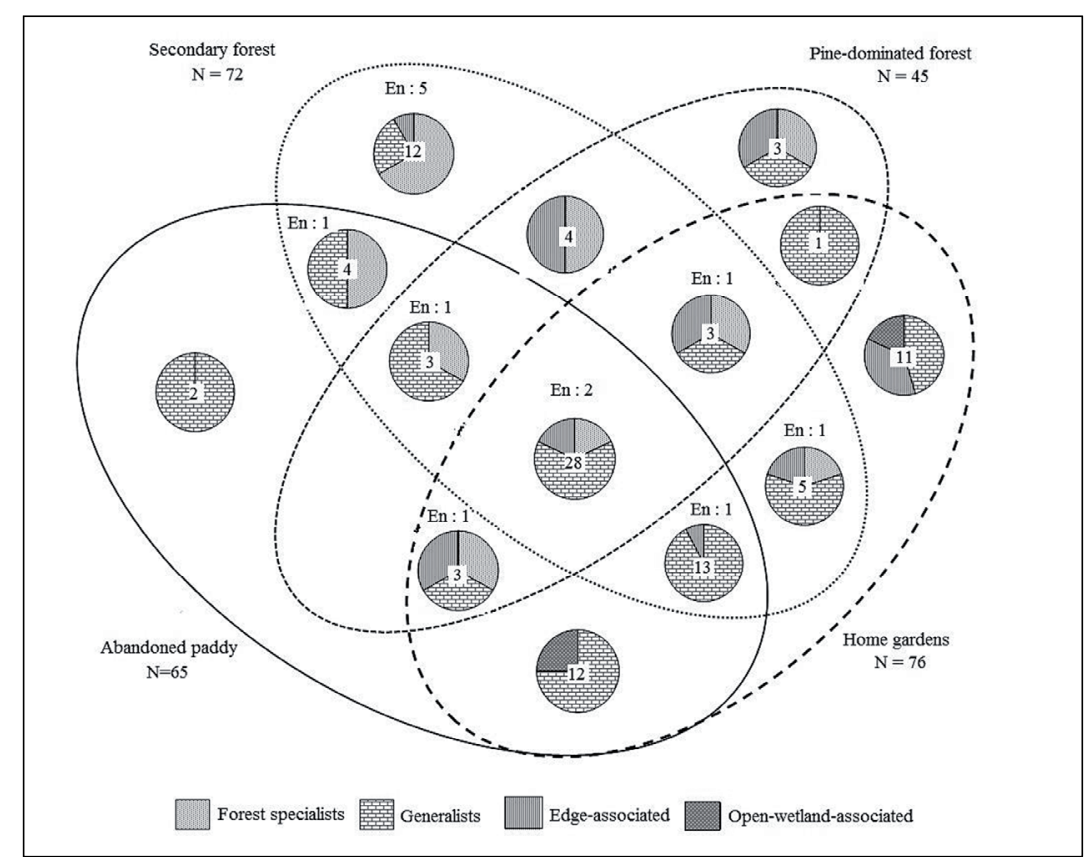

Figure 5. Relative abundance of feeding guilds in each habitat.

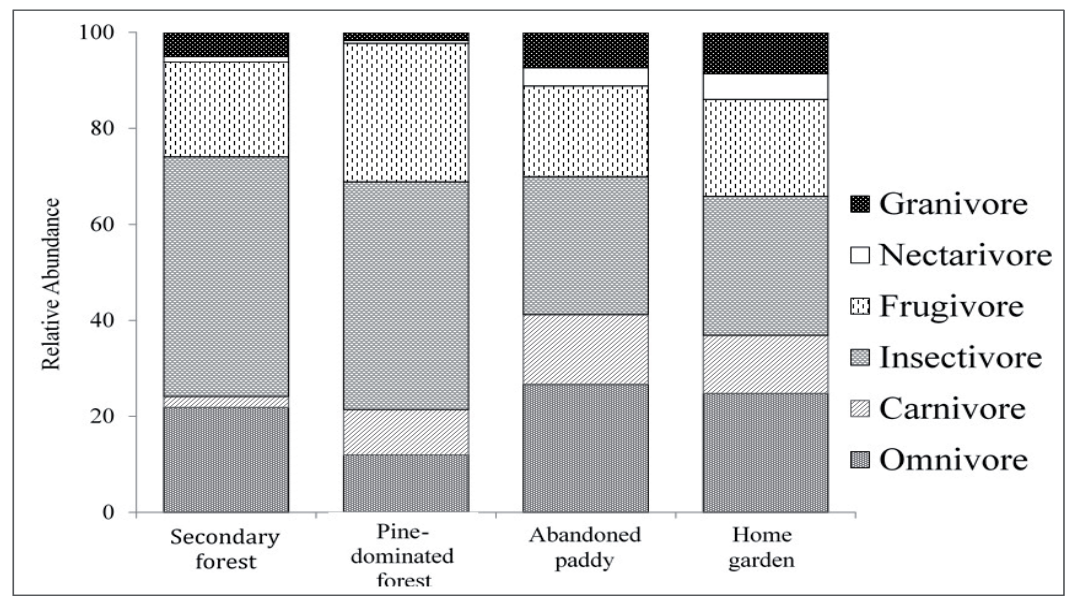

Among the endemic species, Sri Lanka Hanging Parrot (Loriculus beryllinus) and Sri Lanka Yellow-fronted Barbet (Megalaima flavifrons) were recorded from all four habitat types. Sri Lanka Green-billed Coucal (Centropus chlororhynchus), Sri Lanka Blue Magpie (Urocissa ornate) and Sri Lanka Spot-winged Thrush (Zoothera spiloptera) were recorded only in secondary forest. Sightings of Stork-billed Kingfisher (Pelargopsis capensis) were restricted to abandoned paddy lands, while other aquatic and semi-aquatic species such as Cattle Egret (Bubulcus ibis) and White-breasted Waterhen (Amaurornis phoenicurus) were more abundant in abandoned paddy lands.

\section{Habitat association of feeding guilds}

As indicated in the Appendix, insectivores were the richest feeding guild, with 48 species, followed by carnivores (19 species), omnivores (18 species), frugivores (12 species), granivores (four species) and nectarivores (three species).
Insectivores were the dominant feeding guild in all four vegetation types studied. The relative abundance of insectivores was high in forested habitats, i.e., secondary-forest and pinedominated forest (Fig. 5). Differences in the relative abundance of each feeding guild among habitats were tested using One-way ANOVA. Only the abundance of omnivore $(\mathrm{F}=$ $2.918, p=0.034)$ and granivore $(F=3.299, p=0.024)$ feeding guilds showed statistically significant differences among habitats. Tukey's post-hoc comparisons revealed significant differences in the abundance of granivores between the secondary forest and abandoned paddy lands $(p=0.04)$ and omnivores between the pine-dominated forest and abandoned paddy lands $(\mathrm{p}=0.029)$.

\section{Discussion}

Our study demonstrates that edge habitats of fragmented tropical forest patches are more diverse in terms of avifauna than the forest interior and are also important for endemic for- 
est specialist birds. Habitat edges or ecotones are often considered landscape structures that influence bird communities, and bird communities respond differently to structurally complex edges (Vâlcu 2006). The forest-home-garden interface sampled in this study predominantly consisted of tea, grown under shade trees with a mixture of multi-purpose trees and fruit trees present in home gardens. Similar croplands in the interface managed under shade trees elsewhere in the tropics have reported comparable observations, with high numbers of resident and migratory bird species recorded from such edge habitats compared to the forest interior (Estrada et al. 1997, Van Bael et al. 2007). Bird diversity and composition in agricultural lands in the wet tropics are strongly influenced by the availability of diverse groups of trees and patches of secondary growth (Daily et al. 2001, Hughes et al. 2002). This, along with the variety of foraging opportunities present in home gardens bordering the forest may explain the high bird diversity and richness at the forest-home-garden interface. Abandoned paddy lands, on the other hand, are dominated by grasses and structurally less diverse, and hence accounted for less bird richness. However, several endemic forest specialists such as Sri Lanka Grey Hornbill, Pompadour Green Pigeon, Sri Lanka Crested Drongo, Sri Lanka Yellow-fronted Barbet, Sri Lanka Spurfowl and Sri Lanka Emerald-collared Parakeet also use edge habitats located inside or bordering the forest.

The two forest interior habitats surveyed in this studythe secondary forest and pine-dominated forest- showed noticeable differences in structure and heterogeneity in vegetation. As suggested by previous studies, the greater structural heterogeneity of vegetation and vertical stratification in the secondary forest provide diverse resources, enabling a higher number of bird species to reside (Blake and Loiselle 2001, DeWalt et al. 2003, Blake 2007, Barzan et al. 2015, Casas et al. 2016). Furthermore, the study's findings highlight the importance of secondary forest fragments for endemic and forest specialist birds. Forest interior species are more sensitive to human disturbance and tend to actively avoid edge habitats (Alwis et al. 2016). Endemic forest specialist species such as the Sri Lanka Green-billed Coucal, Sri Lanka Spot-winged Thrush, and Sri Lanka Magpie avoided the forest-home garden interface and Pinus-dominated forest, likely due to the structural unsuitability of vegetation (Raman and Sukumar 2002). Additionally, certain vulnerabilities associated with edge habitats, such as inappropriate feeding, resting, escape and nesting cover, may have confined these species to the forest interior (Villard 1998, Mörtberg 2001).

Monoculture exotic forest crops generally support low avifaunal diversity (Marsden et al. 2001). Consistent with previous observations (Goodale et al. 2013), this study also found that Pinus-dominated forest supported less native bird diversity. Nonetheless, the Pinus-dominated forest surveyed in this study is in the process of being colonized by native vegetation, and thus features rather diverse habitat characteristics compared to typically managed monocultures. Our study recorded nine forest specialists and five endemics from the Pinus-dominated forest. Sri Lanka Grey Hornbill, Pompadour Green Pigeon and Sri Lanka Yellow-fronted
Barbet showed particularly high abundance in the pine-dominated forest. Hence, areas restored with exotic tree species such as non-native conifers may be particularly important for forest bird communities in areas where little natural or seminatural forests remain (Irvin et al. 2014).

Studies in the tropics have reported that understory insectivores and omnivores tend to be more associated with intermediate successional forests and secondary forests (Raman et al. 1998, Pinotti et al. 2012, Casas et al. 2016). This can be attributed to the abundant availability of moisture-dependent insects and shade-dependent plants/fruits in these habitats (Villard 1998, Pinotti et al. 2012). This probably explains why insectivore and frugivore feeding guilds dominate the secondary forest habitat in this study. Spot-bellied Eagle Owl and Blyth's Reed Warbler were recorded only in Pinusdominated forest. Blyth's Reed-warbler (Acrocephalus dumetorum) preferred foraging heights of up to $1 \mathrm{~m}$ (Gokula 2001). As the Pinus-dominated forest contained numerous dead and decaying pine trees and a mixture of native vegetation with a dense Ochlandra stridula undergrowth, this habitat is conducive for insectivores due to abundant insects and other arthropods.

Shikra, White-bellied Sea Eagle, Booted Eagle, Ashy Wood Swallow, Bar-winged Flycatcher-shrike, Drongo Cuckoo, Common Hawak-cuckoo, House Sparrow and Coppersmith Barbet were only recorded from home gardens. It was further observed that habitat edges are rich in raptors and other birds of prey (carnivore feeding guild). This may be due to an increased amount of microhabitats, visibility and prey (Kottawa-Arachchi et al. 2012, Wijesundara and Wijesundara 2014). A high abundance of granivores in edge habitats may be explained by the presence of grassy vegetation and domestic kitchen waste disposed of in home gardens, which attracts granivores. The availability of such easily accessible food sources, especially in home gardens, has likely caused an influx of opportunistic and non-forest omnivore species (Gray et al. 2007).

In this study, we found two distinct bird assemblages occupying various habitats from the forest edge to interior, representing different levels of disturbance. The bird assemblage in the forest interior was dominated by insectivore and frugivore feeding guilds and included forest specialists. The bird assemblage in the edge habitats predominantly included habitat generalists, with insectivore, omnivore, frugivore and carnivore feeding guilds equally abundant. Extensive data gathered in this study permit similarity analyses of bird assemblages. However, as some habitats were under-sampled (as suggested by rarefaction curves), these findings should be treated cautiously.

\section{Conclusion}

The findings of this study contribute to the limited information related to avian community ecology in fragmented and isolated tropical wet evergreen forest patches in the south-west lowlands of Sri Lanka. Our results indicate that although it is a fragmented and isolated forest patch, the 
Yagirala Forest Reserve and the associated ecotone collectively provide an important refuge for avifauna in the landscape context. Five endemic bird species were confined to the secondary forest, while the highest number of forest specialists and endemic species were recorded from the secondary forest, followed by the Pinus-dominated forest. Hence, we conclude that less-disturbed habitats are more important for forest specialist birds. Further losses of secondary forest and reduced patch size would negatively impact these bird populations. Hence, keeping the secondary forest intact and devoid of human disturbance is essential in avian conservation efforts. Though structurally less complex than the secondary forest, Pinus-dominated forest can potentially provide important habitats for native forest birds. Selective removal of mature pine trees and enrichment with native plant species can enhance the utility of such restored forests for native forest birds. This study further provides baseline data to show that moderately disturbed habitats associated with fragmented forests are important sites for both forest and non-forest bird species. As such, enrichment of home gardens' native vegetation will be beneficial in landscape level conservation efforts focused on tropical avifauna.

Acknowledgements. The authors wish to acknowledge the Center for Sustainability, Department of Forestry and Environmental Science, University of Sri Jayewardenepura for facilitating the research, and C. Deshapriya, T. Perera, R. de Mel, A. Sumanapala, P. Gunawardana, and C. Munasinghe for their assistance during field work. The authors especially acknowledge the constructive comments of anonymous reviewers, which improved the manuscript substantially.

\section{References}

Alwis, N.S., P. Perera and N.P. Dayawansa. 2016. Response of tropical avifauna to visitor recreational disturbances: a case study from the Sinharaja World Heritage Forest, Sri Lanka. Avian Res. $7: 15$.

Antongiovanni, M. and J.P. Metzger. 2005. Influence of matrix habitats on the occurrence of insectivorous bird species in Amazonian forest fragments. Biol. Conserv. 122:441-451.

Bambaradeniya, C.N.B., J.P. Edirisinghe, D.N. De Silva, C.V. S. Gunatilleke, K.B. Ranawana and S. Wijekoon.. 2004. Biodiversity associated with an irrigated rice agro-ecosystem in Sri Lanka. Biodivers. Conserv. 13:1715-1753.

Barzan, F.R., J.M.E. Baigorria and R.F. Bó. 2015. Bird community diversity in three habitat types in an ecological corridor in the Atlantic Forest of Misiones province, Argentina. Trop. Conserv. Sci. 8:955-974.

Beukema, H., F. Danielsen, G. Vincent, S. Hardiwinoto and J. Van Andel. 2007. Plant and bird diversity in rubber agroforests in the lowlands of Sumatra, Indonesia. Agroforest Syst. 70:217-242.

Bhagwat, S.A., K.J. Willis, H.J.B. Birks and R.J. Whittaker. 2008. Agroforestry: a refuge for tropical biodiversity? Trends Ecol. Evol. 23:261-267.

Bibby, C.J. 2000. Bird Census Techniques. Elsevier, Amsterdam.

BirdLife International. 2015. IUCN Red List for birds. www.birdlife. org Date consulted 18-06-2016.
Blake, J.G. 2007. Neotropical forest bird communities: a comparison of species richness and composition at local and regional scales. The Condor 109:237-255.

Blake J.G. and B.A. Loiselle. 2001. Bird assemblages in secondgrowth and old-growth forests, Costa Rica: perspectives from mist nets and point counts. The Auk 118:304-326.

Casas, G., B. Darski, P. Ferreira, A. Kindel and S.C. Müller. 2016. Habitat structure influences the diversity, richness and composition of bird assemblages in successional Atlantic rain forests. Trop. Conserv. Sci. 9:503-524.

Colwell, R.K. 2013. EstimateS: Statistical estimation of species richness and shared species from samples. Version 9. User's Guide and application published at: http://purl.oclc.org/estimates.

Colwell, R.K., A. Chao, N.J. Gotelli, S. Lin, C.X. Mao, R.L. Chazdon and J.T. Longino. 2012. Models and estimators linking individual-based and sample-based rarefaction, extrapolation and comparison of assemblages. J. Plant Ecol. 5:3-21.

Daily, G.C., P.R. Ehrlich and G.A.S. Azofeifa. 2001. Countryside biogeography: use of human-dominated habitats by the avifauna of southern Costa Rica. Ecol. Appl. 11:1-13.

DeWalt, S.J., S.K. Maliakal and J.S. Denslow. 2003. Changes in vegetation structure and composition along a tropical forest chronosequence: implications for wildlife. Forest Ecol. Manag. 182:139-151.

Edirisinghe, E.A.P.N., K.P. Ariyadasa and R.P.D.S. Chandani. 2012. Forest cover assessment in Sri Lanka. Sri Lanka Forester 34:112.

Ekanayake, E. M. B. P. and M. Theodore. 2017. Forest policy for sustainability of Sri Lanka's forest. Internat. J. Sci. 6:28-33.

Estrada, A., R. Coates-Estrada and D.A. Meritt. 1997. Anthropogenic landscape changes and avian diversity at Los Tuxtlas, Mexico. Biodivers. Conserv. 6:19-43.

Fischer, J. and D.B. Lindenmayer. 2007. Landscape modification and habitat fragmentation: a synthesis. Glob. Ecol. Biogeogr. 16:265-280.

Forestry Sector Master Plan. 1995. Forest Department, Ministry of Agriculture, Lands and Forestry of Sri Lanka. Colombo.

Gamito, S. 2010. Caution is needed when applying Margalef diversity index. Ecol. Indic. 10:550-551.

Gibson, L., T. M. Lee, L.P. Koh, B.W. Brook, T.A. Gardner, J. Barlow, C.A. Peres, C.J. Bradshaw, W.F. Laurance, T.E. Lovejoy and N.S. Sodhi 2011. Primary forests are irreplaceable for sustaining tropical biodiversity. Nature 478:378-381.

Gokula, V. 2001. Foraging patterns of birds in the thorn of Mudumalai Wildlife Sanctuary, Southern India. J. South Asian Nat. Hist. 5:143-153.

Goodale, E., S.W. Kotagama, T.S. Raman, S. Sidhu, U. Goodale, S. Parker and J. Chen. 2013. The response of birds and mixed-species bird flocks to human-modified landscapes in Sri Lanka and southern India. Forest Ecol. Manag. 329:384-392.

Gotelli, N.J. and A. Chao. 2013. Measuring and estimating species richness, species diversity, and biotic similarity from sampling data. In: Levin S.A. (ed.) Encyclopedia of Biodiversity, 2nd ed. Volume 5. Academic Press, Waltham, MA. pp. 195-211.

Gray, M.A., S.L. Baldauf, P.J. Mayhew and J.K. Hill. 2007. The response of avian feeding guilds to tropical forest disturbance. Conserv. Biol. 21:133-141.

Harrison, J. 2011. A Field Guide to the Birds of Sri Lanka. Oxford University Press, Oxford.

Henry, G. M. 1998. A Guide to the Birds of Sri Lanka. Oxford University Press, Oxford. 
Herzog, F., S. Dreier, G. Hofer, C. S. B. S. M. Marfurt, B. Schüpbach, M. Spiess and T. Walter. 2005. Effect of ecological compensation areas on floristic and breeding bird diversity in Swiss agricultural landscapes. Agric. Ecosyst. Environ. 108:189-204.

Hughes, J.B., G.C. Daily and P.R. Ehrlich. 2002. Conservation of tropical forest birds in countryside habitats. Ecol. Lett. 5:121129.

Irwin, S., S.M. Pedley, L. Coote, A.C. Dietzsch, M.W. Wilson, A. Oxbrough, O. Sweeney, K.M. Moore, R. Martin, D.L. Kelly and F.J. Mitchell. 2014. The value of plantation forests for plant, invertebrate and bird diversity and the potential for cross-taxon surrogacy. Biodivers. Conserv. 23:697-714.

Johns, A. D. 1991. Responses of Amazonian rain forest birds to habitat modification. J. Trop. Ecol. 7:417-437.

Kottawa-Arachchi, J. D., R. N. Gamage, H. A. C. K. Ariyarathne and G. G. Jayathilake. 2012. Avifaunal diversity in a tea plantation ecosystem in the up-country of Sri Lanka. In: Proceedings of International Forestry and Environment Symposium (Vol. 15)

Legge, W.V. 1983. History of the Birds of Ceylon. 2nd ed. Tisara Prakasakayo, Dehivala, Sri Lanka.

Magurran, A. 2004. Measuring Biological Diversity. Blackwell Publishing, Oxford.

Marsden, S.J., M. Whiffin and M. Galetti. 2001. Bird diversity and abundance in forest fragments and Eucalyptus plantations around an Atlantic forest reserve, Brazil. Biodivers. Conserv. 10:737-751.

Martínez-Morales, M.A. 2005. Nested species assemblages as a tool to detect sensitivity to forest fragmentation: the case of cloud forest birds. Oikos 108:634-642.

Ministry of Environment. 2012. The National Red List 2012 of Sri Lanka; conservation status of the fauna and flora. Colombo, Sri Lanka.

Mörtberg, U. M. 2001. Resident bird species in urban forest remnants; landscape and habitat perspectives. Landscape Ecol. 16:193-203.

Mortelliti, A., S. Fagiani, C. Battisti, D. Capizzi and L. Boitani. 2010. Independent effects of habitat loss, habitat fragmentation and structural connectivity on forest-dependent birds. Divers. Distrib. 16:941-951

Myers, N., R. A. Mittermeier, C. G. Mittermeier, G.A. Da Fonseca and J. Kent. 2000. Biodiversity hotspots for conservation priorities. Nature 403(6772): 853

Noss, R.F. 1991. Sustainability and wilderness. Conserv. Biol. 5:120122.

Pinotti, B.T., C.P. Pagotto and R. Pardini. 2012. Habitat structure and food resources for wildlife across successional stages in a tropical forest. Forest Ecol. Manag. 283:119-127.

Punyawardena, B.V.R., T.M.J. Bandara and M.A.K. Munasinghe. 2003. Agro-ecological Regions of Sri Lanka. Natural Resources Management Center, Department of Agriculture, Sri Lanka.

Raman, T.R., G.S. Rawat and A.J.T. Johnsingh. 1998. Recovery of tropical rainforest avifauna in relation to vegetation succession following shifting cultivation in Mizoram, north-east India. $J$. Appl. Ecol. 35:214-231
Raman, T.R.S. and R. Sukumar. 2002. Responses of tropical rainforest birds to abandoned plantations, edges and logged forest in the Western Ghats, India. Anim. Conserv. 5:201-216.

Ranganathan, J., J. Krishnaswamy and M.O. Anand. 2010. Landscape-level effects on avifauna within tropical agriculture in the Western Ghats: Insights for management and conservation. Biol. Conserv. 143:2909-2917.

Renjifo, L.M. 2001. Effect of natural and anthropogenic landscape matrices on the abundance of subandean bird species. Ecol. Appl. 11:14-31.

Silva, C. P., R.D. Sepúlveda and O. Barbosa. 2016. Nonrandom filtering effect on birds: species and guilds response to urbanization. Ecol. Evol. 6:3711-3720

Spellerberg, I. F. and P.J. Fedor. 2003. A tribute to Claude Shannon (1916-2001) and a plea for more rigorous use of species richness, species diversity and the 'Shannon-Wiener' Index. Glob. Ecol. Biogeogr. 12:177-179.

Sutherland, W.J. 2006. Ecological Census Techniques: A Handbook. Cambridge University Press, Cambridge.

Vâlcu, M. 2006. Seasonal changes in bird species diversity at the interface between forest and reed-bed. Biodivers. Conserv. 15:3459-3467.

Van Bael, S.A., P. Bichier, I. Ochoa and R. Greenberg. 2007. Bird diversity in cacao farms and forest fragments of western Panama. Biodivers. Conserv. 16:2245-2256.

Villard, M.A. 1998. On forest-interior species, edge avoidance, area sensitivity, and dogmas in avian conservation. The Auk 115:801805 .

Waltert, M., A. Mardiastuti and M. Mühlenberg. 2004. Effects of land use on bird species richness in Sulawesi, Indonesia. Conserv. Biol. 18:1339-1346.

Warakagoda, D., C. Inskipp and T. Inskipp. 2012. Birds of Sri Lanka. Christopher Helm, London.

Wijesundara, C. and M. Wijesundara. 2014. Bird diversity of Dekinda Forest Reserve, Balana, Sri Lanka: implications for conservation. Ceylon Journal of Science (Biological Sciences). 43:137-146.

Zurita, G.A., N. Rey and D.M. Varela. 2006. Conversion of the Atlantic Forest into native and exotic tree plantations: Effects on bird communities from the local and regional perspectives. Forest Ecol. Manag. 235:164-173.

Received February 9, 2017 Revised June 19, October 1,2017 Accepted October 12, 2017

\section{Electronic Appendix}

List of species recorded, their conservation status and relative abundance in different habitats. The file may be downloaded from www.akademiai.com. 